\title{
Characterization of track geometric imperfections leading to maximal dynamic amplification of internal forces in railway bridges
}

Caracterização das imperfeições geométricas dos
trilhos que levam à máxima amplificação dinâmica
de esforços solicitantes em pontes ferroviárias

P. G. C. AMARAL a pollyanagca@gmail.com

C. E. N. MAZZILLI a cenmazzi@usp.br

\begin{abstract}
This paper resorts to a simplified dynamic analysis methodology for the study of vibrations in railway bridges produced by the passage of a typical passenger train, or EUT (Electric Unit Train). It starts from a model with fifteen degrees-of-freedom, namely vertical (bounce) and horizontal displacements (sway) and rotations about the longitudinal (roll), transverse (pitch) and vertical (yaw) axes. In this methodology, dynamic models of the train and the bridge are assumed to be initially uncoupled, yet being bound by the interaction train-bridge forces. Thus, the loads are evaluated for the train running on a rigid and fixed deck, considering geometric irregularities, different for each rail line, in both the vertical and horizontal track planes, as well as in the wheels. The contact forces are statically condensed at the vehicle's centre of gravity and applied on a simplified 3D beam model. To represent the train passage over the bridge, functions are used to describe the interaction forces at each node of the beam model, as time evolves. Thus, it is possible to identify the dynamic response caused by the geometric irregularities and also evaluate the dynamic amplification obtained for any internal force, which is compared to the impact coefficient proposed by the Brazilian standards for the design of railway bridges (NBR 7187), used in quasi-static analysis. For the sake of an illustration, a thirty-six-metre-span concrete bridge with box girder section was considered. A study was carried out to find out the parameters of the irregularity functions that could potentially lead to maximal amplification of internal forces in the bridge.
\end{abstract}

Keywords: dynamic analysis, railway bridges, geometric irregularities.

\section{Resumo}

Este trabalho utiliza uma metodologia simplificada de análise dinâmica para o estudo das vibrações em pontes ferroviárias produzidas pela passagem da composição de um trem de passageiros, ou TUE (Trem Unidade Elétrico) típico. Parte-se de um modelo do veículo com quinze graus de liberdade, referentes aos deslocamentos verticais (bounce) e horizontais (sway) e rotações em torno dos eixos longitudinal (roll), transversal (pitch) e vertical (yaw). Nesta metodologia, os modelos dinâmicos do trem e da ponte são tratados de forma inicialmente desacoplada, sendo conectados pelas forças de interação trem-ponte. Desta forma, são calculados os carregamentos provenientes do trem modelado sobre tabuleiro rígido, considerando irregularidades geométricas, diferentes em cada trilho, nos planos vertical e horizontal, e nas rodas. De acordo com esta metodologia, as forças de interacão são condensadas estaticamente no centro de gravidade do veículo e aplicadas em um modelo estrutural simplificado (unifilar) da ponte. Para representar a passagem do comboio sobre a ponte, são utilizadas funções que descrevem as forças de interação trem-ponte em cada nó do modelo unifilar, em cada instante. Com isso, é possível identificar a resposta dinâmica proveniente das irregularidades geométricas e, ainda, avaliar a amplificação dinâmica obtida para cada esforço, a qual é comparada com o valor do coeficiente de impacto utilizado em análises quase-estáticas prescrito na norma brasileira para projeto de pontes ferroviárias (NBR 7187). A título de ilustração, foi considerada uma ponte de concreto de seção celular, com vão de $36,0 \mathrm{~m}$ de comprimento. Foi realizado um estudo a fim de encontrar os parâmetros das funções das irregularidades que levassem à condição mais desfavorável para a amplificação de esforços solicitantes na ponte.

Palavras-chave: análise dinâmica, pontes ferroviárias, irregularidades geométricas. 


\section{Characterization of track geometric imperfections leading to maximal dynamic amplification of internal}

forces in railway bridges

\section{Introduction}

This work refers to vibration analysis of railway bridges, produced by the passage of a typical passenger train composition, or EUT (Electric Unit Train). For this purpose, a simplified methodology will be presented for the dynamic analysis, considering the uncoupled vehicle and the bridge models, in order to facilitate the interaction analysis and also, being able to use current and available computational tools for structural analysis via the Finite Element Method. In order to simulate the dynamic load produced by the composition wagons, the model proposed by Correa [6] is used. In this model, the degrees of freedom of bounce and rotations around the longitudinal (roll) and transverse axes (pitch) for both the wagon suspended mass and the two bogies are considered, totalling nine degrees of freedom. The degrees of freedom related to the horizontal transverse displacement (sway) and rotations about the composition's vertical axis (yaw) are added, being of particular interest for the excitation of bending modes in the horizontal plane of the bridge and horizontal reactions at the top end of the columns, which is especially important for the analysis of the meso- and the infrastructure, obtaining, then, a fifteen-degree-of-freedom model for the vehicle.

The influence of the rail geometric irregularities on the train-rail dynamic interaction in the horizontal and vertical planes and on the wheels is analysed. Together, they can potentially excite the vehi- cle and the bridge vibration modes. To achieve this goal, functions proposed in the literature are used to represent these irregularities, according to [6], in order to find out parameters that maximize the efforts of the bridge, from studies already performed by Cunha [7]. The vehicle and bridge models, as well as the train-rail dynamic interaction, are studied using the dynamic modelling and dynamic analysis software ADINA - Automatic Dynamic Incremental Nonlinear Analysis [1], available in the Computational Mechanics Laboratory of the Polytechnic School of the University of São Paulo.

The investigations start with the modal analysis of the car mechanical-structural system, considering the fifteen degrees of freedom mentioned before, as well as the bridge modal analysis, using a three-dimensional model using shell finite elements. After that, considering rigid rails and wheels, but with geometric irregularities, a mobile loading model with five degrees of freedom is proposed. This mobile loading comes from the interaction forces statically condensed at the vehicle centre of mass. It is also considered the eccentricity of the mobile load with respect to the bridge longitudinal axis. These five forces are applied at a point that runs at a certain constant speed along the 'unifilar' model of the bridge (represented only by its longitudinal axis), associated with the high hierarchy model, constructed with 3D-beam elements.

Finally, it is possible to analyse the dynamic effects on the railway bridges and compare them to those resulting from the use of the impact coefficients adopted by the Brazilian standard (NBR 7187).

\section{Table 1}

Car mechanical and dynamic parameters

\begin{tabular}{|c|c|c|}
\hline Parameter & Unit & Value \\
\hline Wagon mass $\left(m_{s}\right)$ & $\mathrm{kg}$ & 50990 \\
\hline Wagon inertia moment of mass in roll $\left(\mathrm{I}_{\mathrm{xs}}\right)$ & $\mathrm{kg} \mathrm{m}^{2}$ & $1.55 \times 10^{5}$ \\
\hline Wagon inertia moment of mass in pitch $\left(\mathrm{I}_{\mathrm{y}}\right)$ & $\mathrm{kg} \mathrm{m}^{2}$ & $1.96 \times 10^{6}$ \\
\hline Wagon inertia moment of mass in yaw $\left({ }_{z s}\right)$ & $\mathrm{kg} \mathrm{m}^{2}$ & $1.88 \times 10^{6}$ \\
\hline Bogie mass $\left(m_{t}\right)$ & $\mathrm{kg}$ & 4360 \\
\hline Bogie inertia moment of mass in roll $\left(\mathrm{I}_{\mathrm{x} x}\right)$ & $\mathrm{kg} \mathrm{m}^{2}$ & $1.47 \times 10^{3}$ \\
\hline Bogie inertia moment of mass in pitch $\left(\mathrm{l}_{\mathrm{v}}\right)$ & $\mathrm{kg} \mathrm{m}^{2}$ & $3.43 \times 10^{3}$ \\
\hline Bogie inertia moment of mass in yaw $\left(\mathrm{I}_{\mathrm{Zt}}\right)$ & $\mathrm{kg} \mathrm{m}^{2}$ & $5 \times 07 \times 10^{3}$ \\
\hline Primary-suspension vertical stiffness $\left(k_{\mathrm{tv}}\right)$ & $\mathrm{kN} / \mathrm{m}$ & 2976 \\
\hline Primary-suspension lateral stiffness $\left(k_{t h}\right)$ & $\mathrm{kN} / \mathrm{m}$ & 20000 \\
\hline Secondary-suspension vertical stiffness $\left(k_{\mathrm{sv}}\right)$ & $\mathrm{kN} / \mathrm{m}$ & 1060 \\
\hline Secondary-suspension lateral stiffness $\left(k_{\text {sh }}\right)$ & $\mathrm{kN} / \mathrm{m}$ & 460 \\
\hline Primary-suspension vertical damping $\left(\mathrm{C}_{\mathrm{tv}}\right)$ & $\mathrm{kNs} / \mathrm{m}$ & 15 \\
\hline Primary-suspension lateral damping $\left(\mathrm{C}_{\text {tn }}\right)$ & $\mathrm{kNs} / \mathrm{m}$ & 15 \\
\hline Primary-suspension vertical damping $\left(\mathrm{C}_{\mathrm{sv}}\right)$ & $\mathrm{kNs} / \mathrm{m}$ & 30 \\
\hline Primary-suspension lateral damping $\left(\mathrm{C}_{\text {sh }}\right)$ & $\mathrm{kNs} / \mathrm{m}$ & 30 \\
\hline Vehicle total length & $\mathrm{m}$ & 22.5 \\
\hline Distance between bogies $\left(2 \mathrm{I}_{\mathrm{x}}\right)$ & $m$ & 15.6 \\
\hline Distance between axles $\left(2 d_{x}\right)$ & $m$ & 2.5 \\
\hline Distance $\mathrm{I}_{\mathrm{z}}$ & $\mathrm{m}$ & 0.98 \\
\hline Distance $a_{z}$ & $\mathrm{~m}$ & 0.36 \\
\hline Distance $b_{z}$ & $\mathrm{~m}$ & 0.07 \\
\hline Distance $d_{y}$ & $m$ & 0.98 \\
\hline Distance I & $m$ & 1.12 \\
\hline
\end{tabular}



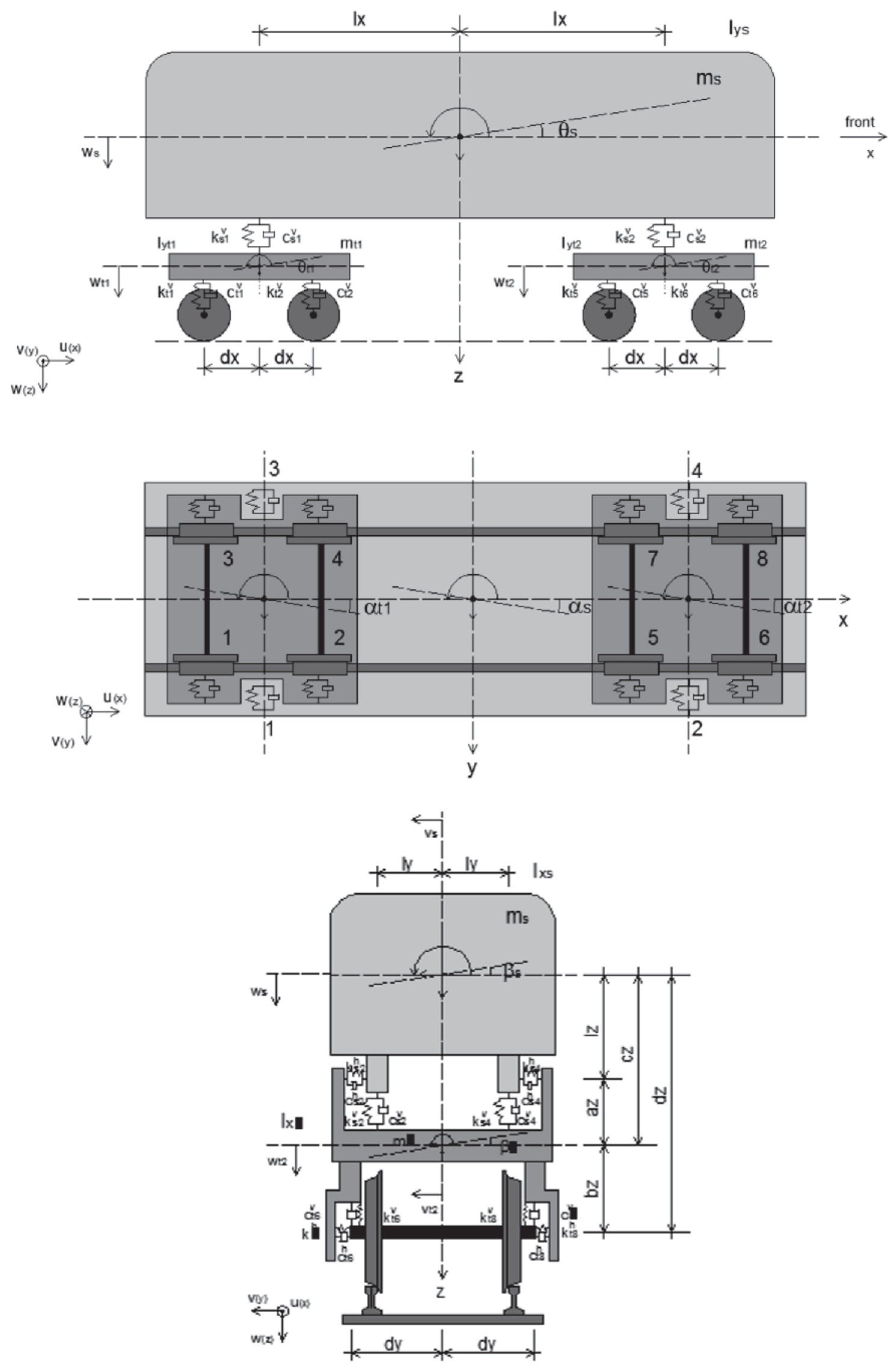

Figure 1

Car dynamic model 


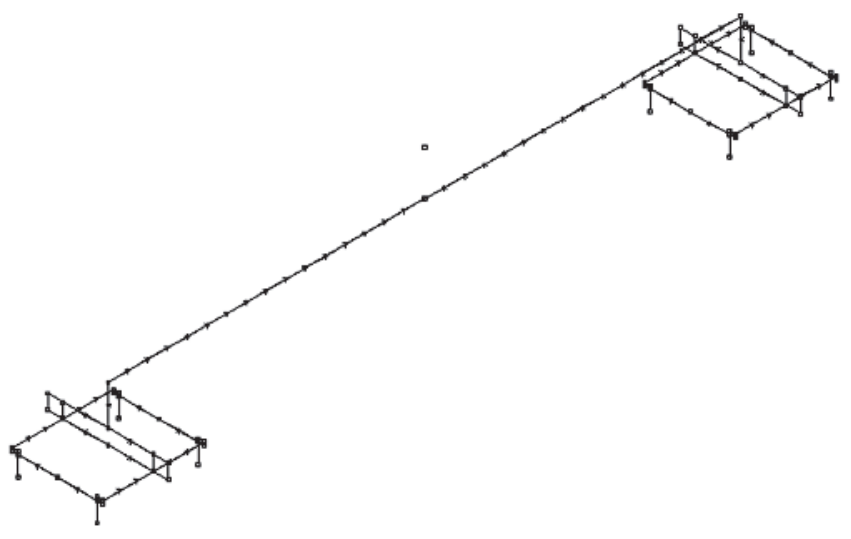

Figure 2

Car model

\section{Modelling}

\subsection{Vehicle model}

Fifteen degrees of freedom are considered for the car modelling as mentioned before. In the absence of complete geometric and mechanical information for the wagons used in the Brazilian railways, the vehicle model presented in [13] is used and its mechanical and dynamic parameters are presented in Table 1. Figure 1 depicts the dynamic model used.

In this work, a composition of two EUTs is used as an example, with four equal wagons, totalling eight cars.

In the three-dimensional dynamic model, with fifteen degrees of freedom for each car, two bogies (front and rear) are considered, suspended masses are assumed as rigid bodies and the mass of the wheels are not taken into account. It is assumed that the wheels do not lose contact with the rails and that they are nondeformable, although they can move vertically and laterally due to wheel's and rail's irregularities. Figure 2 illustrates the car, as modelled in ADINA, using rigid elements interconnected by springs and dampers.

\subsection{Geometric irregularities on rail and wheels}

The dynamic effect of the irregularities is to increase the load to be transferred from the car to the bridge. The rail irregularities are assumed to be undulations, both vertical and horizontal, described by harmonic functions (Figure 3). They can potentially cause sig-

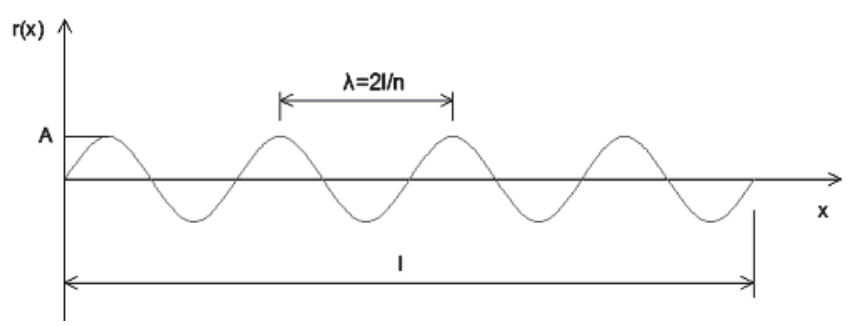

Figure 3

Simple harmonic irregularity nificant vibrations in both the car and the bridge, especially when their wave length $\lambda$, travelled at a speed $V$, leads to a frequency $\frac{2 \pi V}{\lambda}$ close to some natural frequency of the former or the latter.

Phase differences between irregularities, both in the vertical and horizontal planes, as well as between the two rails, are allowed. According to Majka et al [11], the bridge lateral responses are strongly influenced by irregularities in the horizontal plane, since these are the main excitation sources in this direction, in straight bridges, when there are no centrifugal forces to be considered. In the case of wheels, there may be localized notches on the wheel contact surface, since the material constituting them is softer than that of the rails. To characterize these imperfections, the following mathematical models are considered, as presented in Correa [6].

a) Longitudinal irregularity of rails:

For the longitudinal irregularities in the vertical and horizontal planes, it is considered the function:

$r(x)=A \operatorname{sen}\left(\frac{2 \pi x}{V}+\Phi\right)$

where $A$ (in $\mathrm{m}$ ) is the amplitude of the irregularity, $x=V t$ (in $\mathrm{m}$ ) is the space traveled by the car, $V$ (in $\mathrm{m} / \mathrm{s}$ ) is the speed of the car, $\lambda=\frac{2 \ell}{n}$ is the wavelength, $\ell$ is the length with irregularities, $n$ is the number of half waves in $\ell$ and $\Phi$ is the phase angle.

b) Wheel irregularity

Wheel's irregularities are described by the function:

$r(x)=\left\{\begin{array}{c}\frac{1}{2} a_{i}\left[1-\cos \frac{2 \pi}{b_{i}}\left(x-k A_{i}-B_{i}\right)\right], \begin{array}{l}\text { if } \quad B_{i}+k A_{i} \leq x \leq B_{i}+k A_{i}+b_{i} \\ \text { if } B_{i}+k A_{i}+B_{i}<x<B_{i}+(k+1) A\end{array} \\ 0,\end{array}\right.$

where $A_{i}, B_{i}, a_{i}$ and $b_{i}$ are indicated in Figure 4, the i-th wheel with notches, for $k: 0,1,2 \ldots$

The following notation is adopted (Figure 5): $A_{i}$ : circumference length; $B_{i}$ : distance of the first impact of the wheel in relation to the beginning of the bridge; $a_{i}$ : notch depth $\mathrm{e} ; b_{i}$ : notch length.

To represent the rail's and the wheel's irregularities, displacements are applied in the wheel-rail contact, according to the functions presented, in the vertical and horizontal planes.

\subsection{Structural modelling}

The bridge used in the model was extracted from [4]. It is a subway bridge in reinforced concrete, with double track, whose eccentricity

$r(x)$

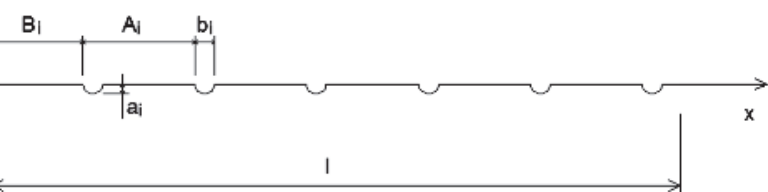

Figure 4

Irregularities in wheels 


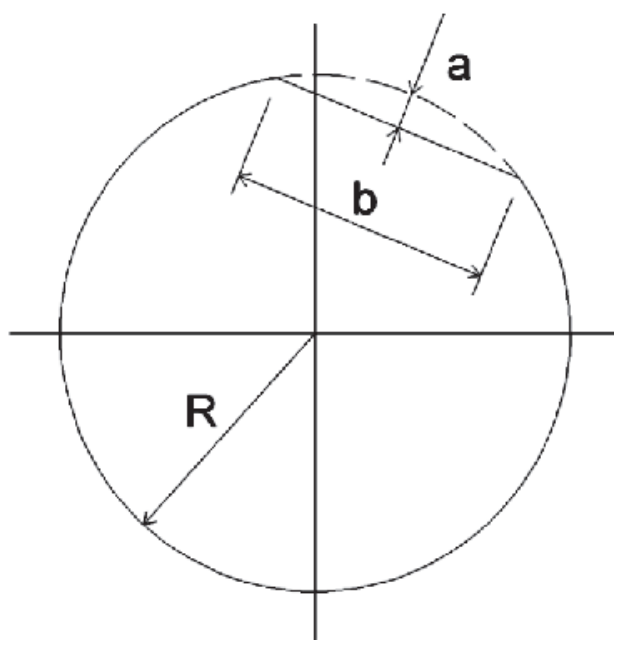

Figure 5

Wheel with a notch

of the track is $2.4 \mathrm{~m}$, and with a simply-supported span $36 \mathrm{~m}$ in length. The cross section is a box-girder, with dimensions and properties shown in Figure 6 and Table 2. An isotropic linear model for concrete with a compressive strength equivalent to $25 \mathrm{MPa}$ and a modulus of elasticity of $2.38 \times 10^{10} \mathrm{kN} / \mathrm{m}^{2}$ was considered.

For the modal analysis, a high hierarchy model of the bridge was used in order to present a reasonable characterization of the vibration frequencies for the higher modes. Thus, a three-dimensional simply-supported model of the bridge was adopted, using shell finite elements ('shell' element of ADINA), using a regular mesh discretization of approximately $0.5 \mathrm{~m}$ and defining the geometry from the axis of the structural elements. Figure 7 illustrates the high-order model built in ADINA.

\subsection{Car and bridge reduced order model}

Although the 'unifilar' low-hierarchy models do not have a good match with the high-mode vibration frequencies, due to their simplicity, they are adopted for the bridge and the car dynamic analysis. It is observed that, in this study, a good proximity was found between the frequencies for the shell and beam 3D element models of the bridge for the lower modes of vibration.

\section{Table 2}

Deck properties

\begin{tabular}{|c|c|c|}
\hline$A$ & 4.56 & $\mathrm{~m}^{2}$ \\
\hline $\mathrm{Ix}$ & 3.52 & $\mathrm{~m}^{4}$ \\
\hline $\mathrm{Iy}$ & 28.88 & $\mathrm{~m}^{4}$ \\
\hline $\mathrm{It}$ & 6.68 & $\mathrm{~m}^{4}$ \\
\hline$E$ & $2.38 \times 10^{10}$ & $\mathrm{~N} / \mathrm{m}^{2}$ \\
\hline $\mathrm{m}$ & 11169.84 & $\mathrm{~kg} / \mathrm{m}$ \\
\hline $\mathrm{Ir}_{\mathrm{x}}$ & 39273.16 & $\mathrm{~kg} \mathrm{~m}$ \\
\hline $\mathrm{Ir}_{y}$ & 1134090.97 & $\mathrm{~kg} \mathrm{~m}$ \\
\hline
\end{tabular}

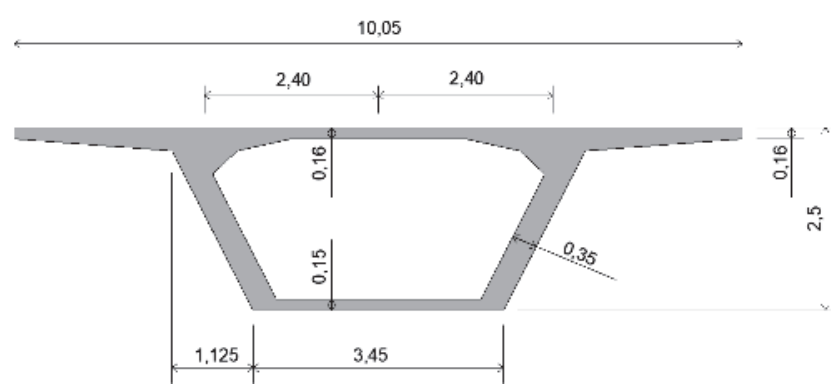

Figure 6

Cross section of bridge (measures in $\mathrm{m}$ )

In order to obtain the car reduced-order model, static forces are condensed at each wheel-rail contact to the vehicle gravity centre. Thus, the loading model was reduced to five forces applied at that point, which move at a constant velocity $V$ on the bridge, namely: bounce force, sway force, pitch moment, roll moment and yaw moment. With the efforts statically condensed in the car gravity centre, we proceed to the modelling of the train traveling on the bridge. These efforts are applied to a low-hierarchy bridge model ('unifilar' model), consisting of finite elements of three-dimensional rods (ADINA 'beam' elements) whose properties are the same as those used for the modal analysis (Table 2). The bridge is considered as simply supported and it is discretized in 72 bar elements of $0.5 \mathrm{~m}$ each, and in each node of the discretized model the five reduced efforts are specified, over time, simulating the passage of the train's eight cars. Thus, at the instant that the train is over the node, the five reduced efforts are specified and, for the other instants, these values are zero. It is observed that a linear dynamic analysis is performed using the implicit integration method of Newmark.

It should be noted that, for the analysis, Rayleigh coefficients are considered for a modal damping of $3 \%$, referring to the first and fifth mode of vibration of the bridge $(3.307$ and $16.30 \mathrm{~Hz})$, both of bounce. The frequencies and the modes obtained for the bridge's modal analysis are presented in Table 3.

\section{Results and comments}

First of all, it should be mentioned that the example considered

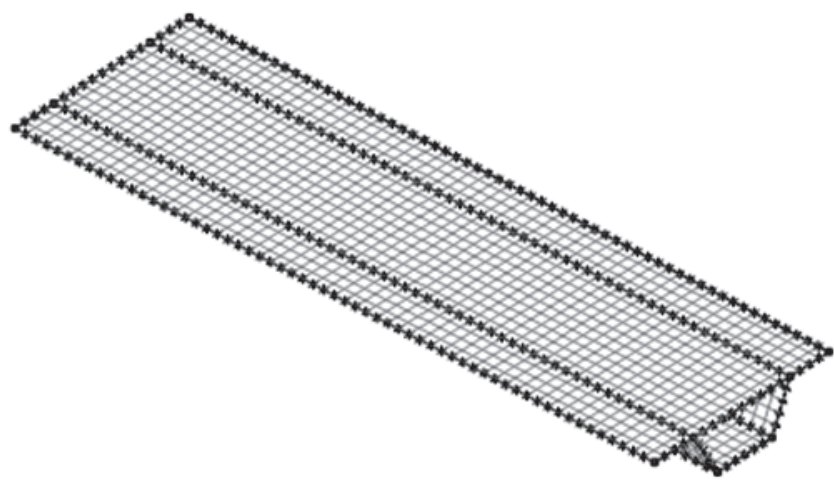

Figure 7

Shell-element finite-element model used for the bridge 
Table 3

Vibration modes

\begin{tabular}{|c|c|c|c|c|}
\hline Modes & $\begin{array}{l}\text { Bridge frequency } \\
(\mathrm{Hz})\end{array}$ & Bridge modes & $\begin{array}{c}\text { Car frequency } \\
(\mathrm{Hz})\end{array}$ & Car modes \\
\hline $1^{\circ}$ & 3.307 & Bending & 0.645 & Roll \\
\hline $2^{\circ}$ & 10.460 & Torsion & 1.215 & Yaw \\
\hline $3^{\circ}$ & 10.560 & Bending & 1.230 & Roll and Sway \\
\hline $4^{\circ}$ & 14.970 & Bending & 1.334 & Bounce \\
\hline $5^{\circ}$ & 16.300 & Bending & 1.667 & Pitch \\
\hline $6^{\circ}$ & 16.730 & Bending & 9.044 & Bounce \\
\hline $7^{\circ}$ & 17.410 & Bending & 9.055 & Bounce \\
\hline $8^{\circ}$ & 17.670 & Bending & 11.720 & Pitch in bogies in the opposite direction \\
\hline $9^{\circ}$ & 18.160 & Torsion & 11.720 & Pitch in bogies in the same direction \\
\hline $10^{\circ}$ & 18.480 & Bending & 15.480 & Roll in bogies in the opposite direction \\
\hline
\end{tabular}

here is not intended to raise doubts on the quasi-static procedures proposed by Brazilian or most international standards, even because, if that were the goal, it would be necessary to consider a representative number of case studies, which is not done here. The purpose of this paper is to demonstrate that the dynamic analysis of railway bridges, with a much more accurate description of phenomena than quasi-static analysis, is within reach for skilled engineers, with the aid of computational tools commonly used for the structural analysis via the finite element method. If such dynamic analyses are more reliable than the quasi-static ones, they will be able to identify, in each case, more economical design opportunities without structural safety concessions or, exceptionally, more critical scenarios than those foreseen by quasi-static procedures. The example considered in this article falls into the first category, which means that the dynamic analysis proves to be less critical

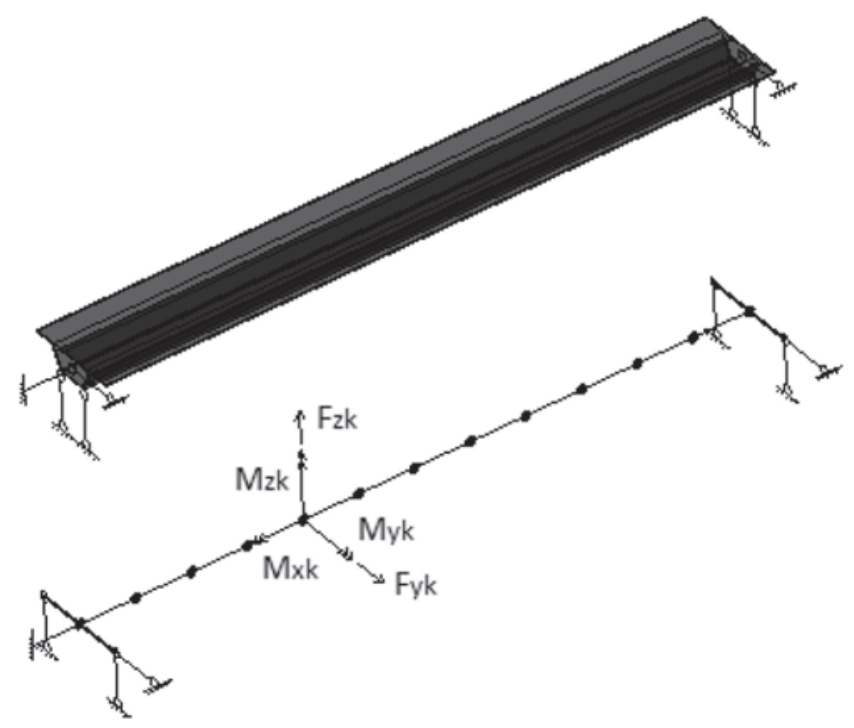

Figure 8

Low-hierarchy model of the bridge ('unifilar' model) than the quasi-static analysis. This is not surprising, since the considered bridge (Brazilian subway bridge) is clearly oversized for the electric vehicle train (Chinese vehicle) used. It should be emphasized that the choice of the vehicle, for the purpose of exemplifying the methodology proposed here, was conditioned by the unavailability of information of all the parameters necessary to analyse the 15 degree of freedom model for the Brazilian subway car. Therefore, the vehicle described by Xia et al [13] was used, since all the parameters necessary for its modelling were available.

According to this perspective, the results of the dynamic analysis simulating the car passage on a rail set directly on the bridge (without ballast), considering the irregularities discussed before, are compared with those resulting from the quasi-static analysis, applying the criteria defined at NBR-7187 "Projeto de Pontes de Concreto Armado e de Concreto Protendido". Although this standard was updated in 2013 and became valid only for road bridges, it was considered in its previous version for this study due to the lack of Brazilian references for railway bridges. It should be recalled that NBR-7189 "Ações em Pontes Ferroviárias" was canceled in July 2015. An alternative could be to use international regulations, such as AREMA [2], whose impact coefficient for this case study would be 1.228 .

Thus, if the former NBR-7187 were applicable, the vertical loads of the vehicle on the bridge should be increased by the impact coefficient:

$\varphi=0,001 \times(1600-60 \sqrt{\ell}+2,25 \ell) \geq 1,2$

In the present case, this impact coefficient would be $\varphi=1.321$ , which is a very high value, due to the bridge small span $(36 \mathrm{~m})$. With regard to the transverse horizontal loads applied by the vehicle to the bridge, the NBR-7187 also proposed a rather high value compared to those that would result from typical rail irregularities, namely $20 \%$ of the vertical load of the heaviest axle!

The quasi-static analyses responses of bending moment in the horizontal and vertical planes and vertical displacement refer to the middle section of the bridge span, while for the torsion moment the section of a quarter of the span is analysed. It should be noted 

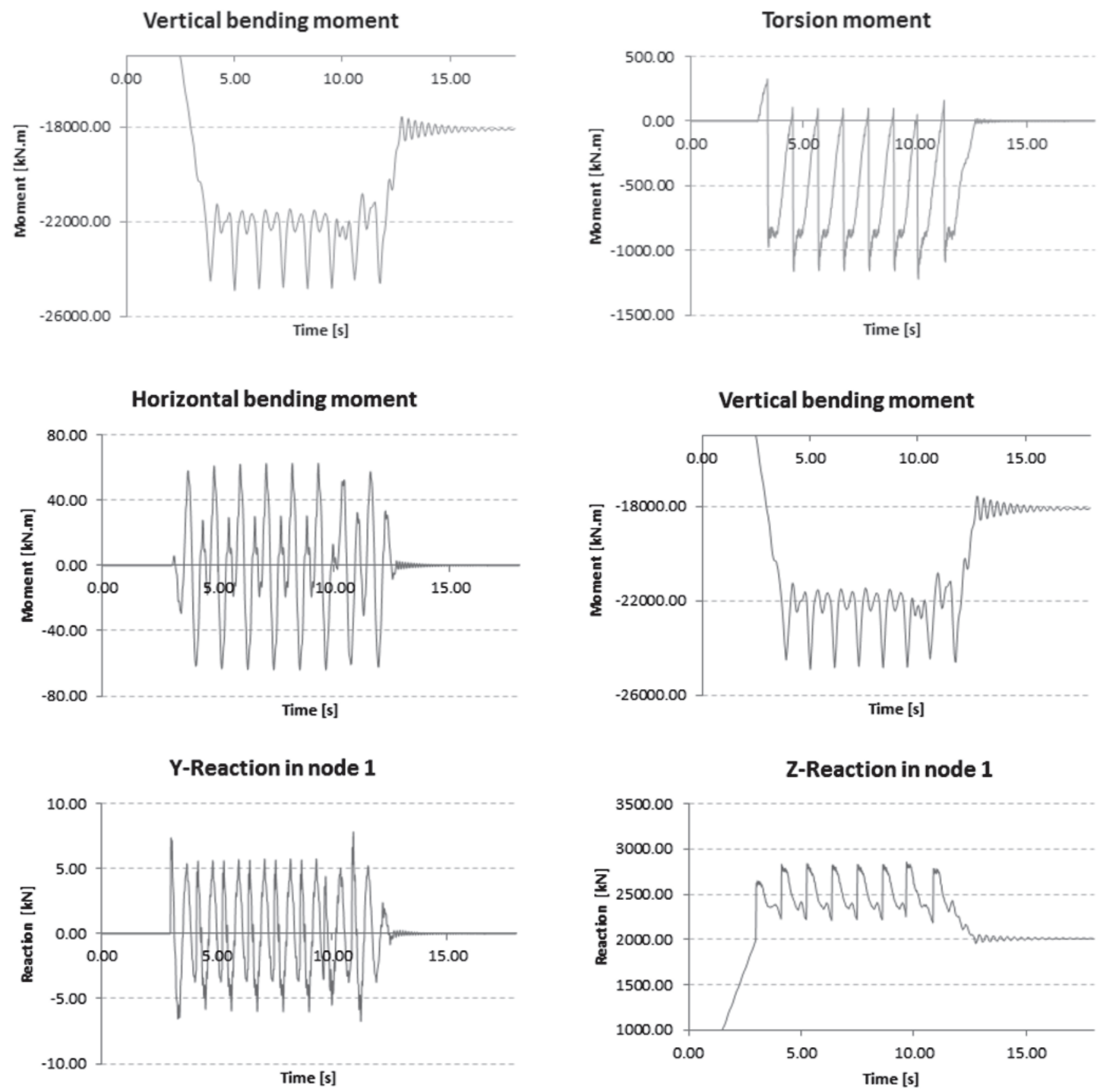

Y-Reaction in node 2

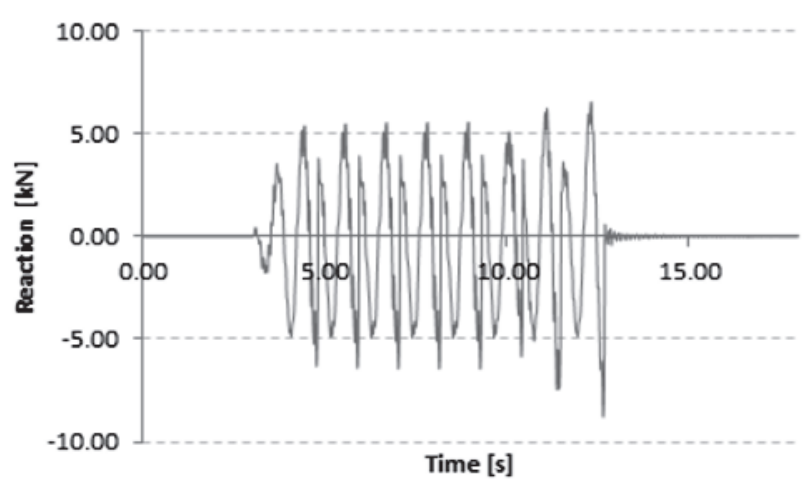

Z-Reaction in node 2

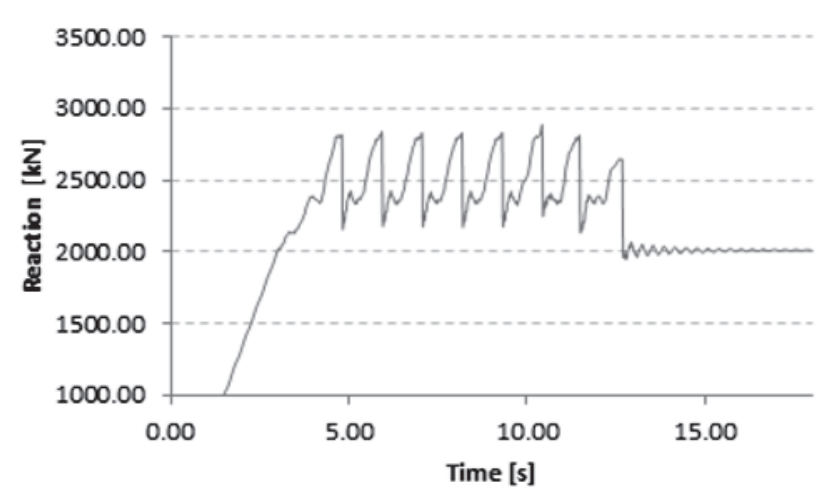

Figure 9

Results - dynamics analysis for $n=5$ 
Characterization of track geometric imperfections leading to maximal dynamic amplification of internal forces in railway bridges
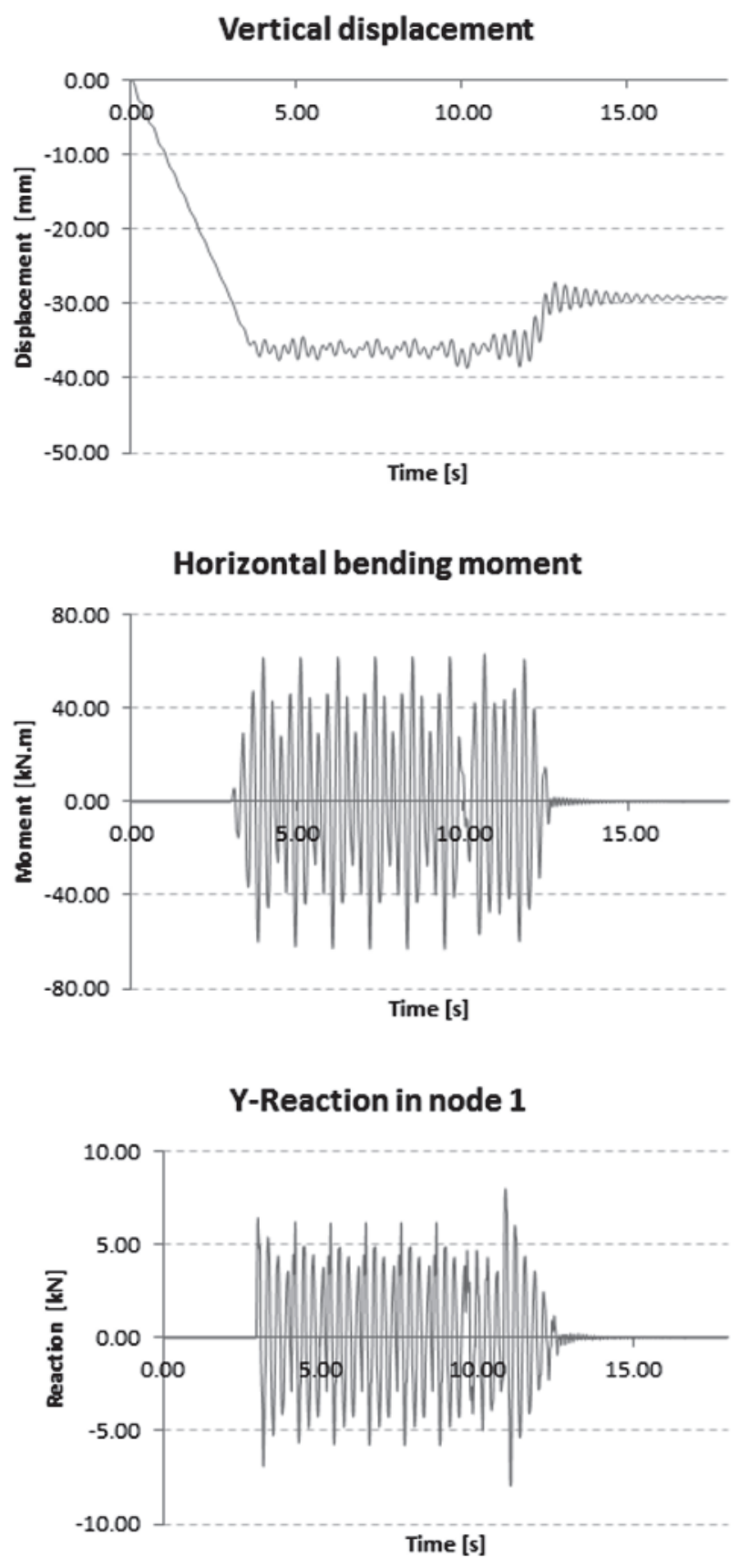

Y-Reaction in node 2

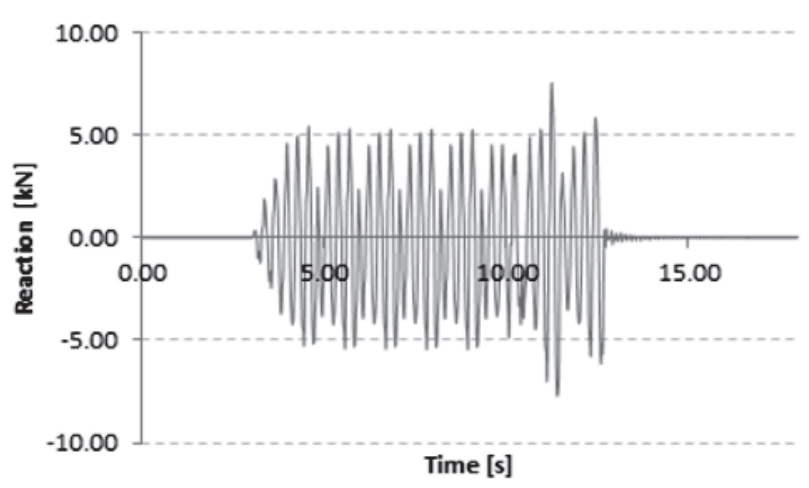

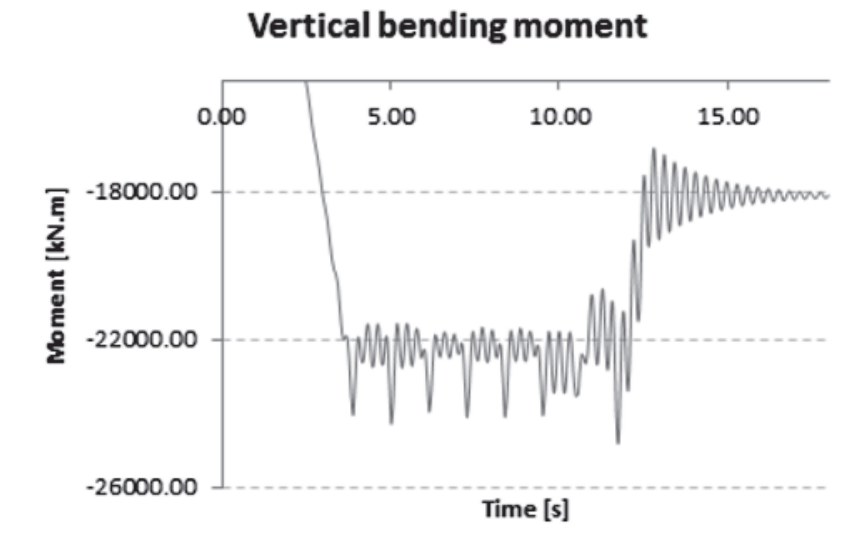
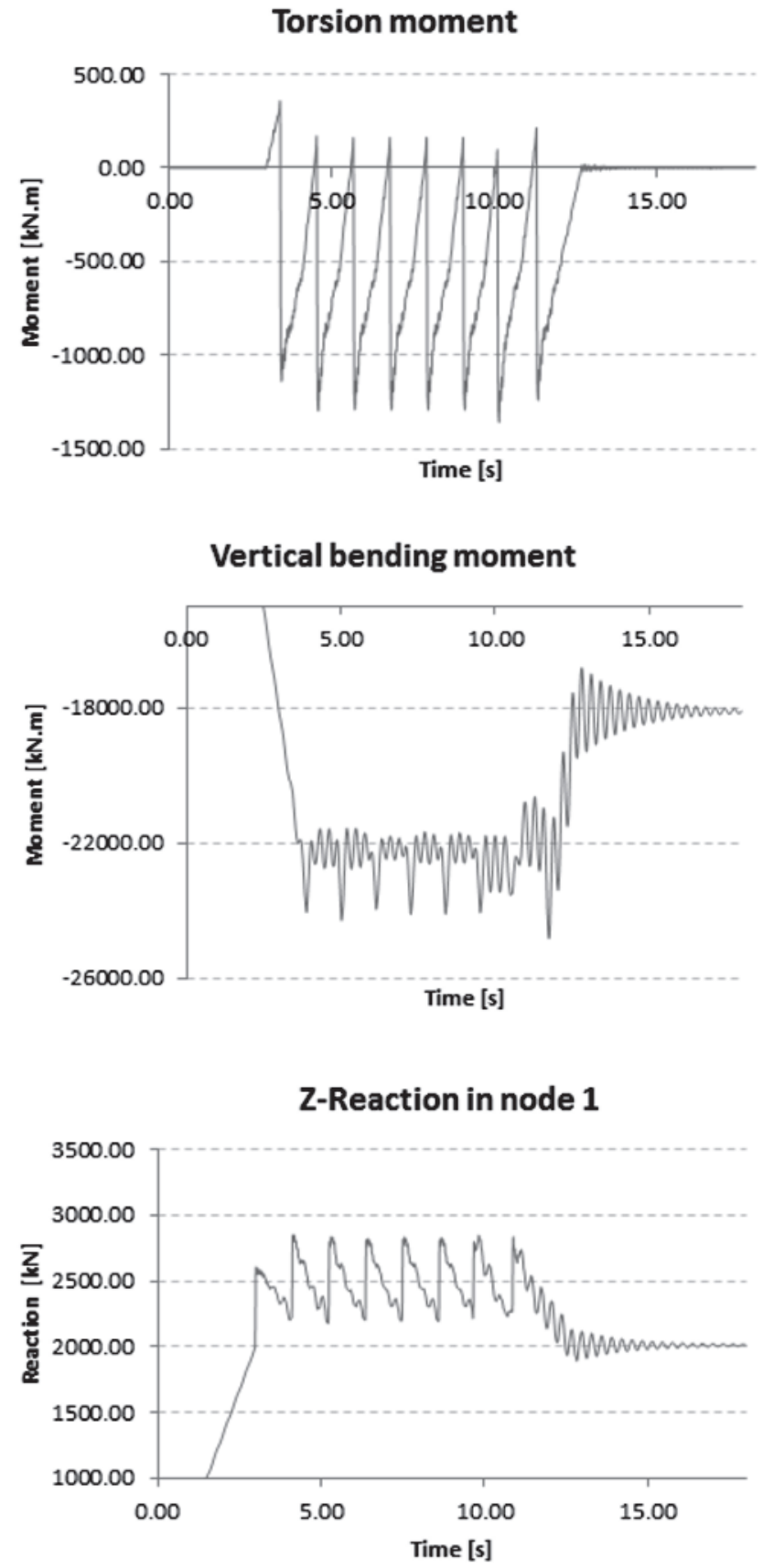

Torsion moment

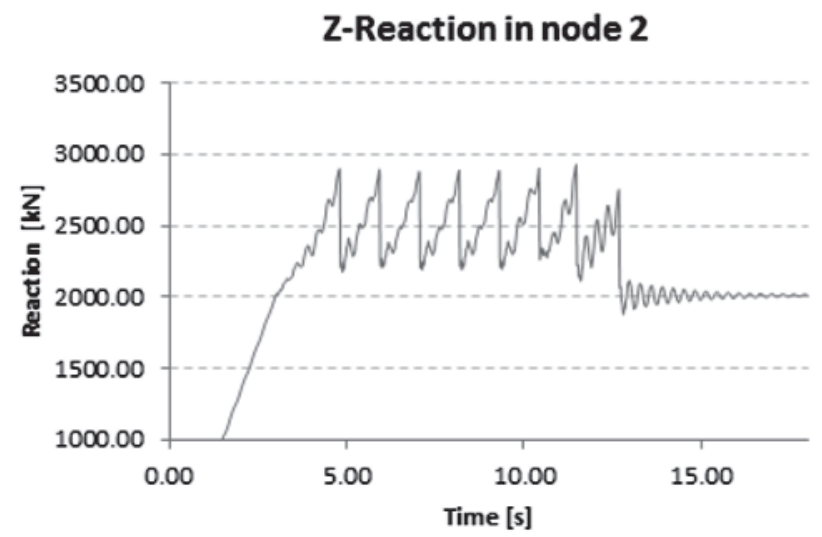

Figure 10

Results - dynamics analysis for $n=11.7$ 
Table 4

Maximum values obtained by each analysis

\begin{tabular}{|c|c|c|c|c|}
\hline \multirow{2}{*}{ Results } & \multirow{2}{*}{$\begin{array}{l}\text { Quasi-static } \\
\text { analysis }\end{array}$} & \multicolumn{3}{|c|}{ Dynamic analysis } \\
\hline & & $\mathrm{n}=\mathbf{5}$ & $\mathrm{n}=8.7$ & $\mathrm{n}=11.7$ \\
\hline Torsion moment (kN m) & -1.677 & -1.223 & -1.347 & -1.358 \\
\hline Horizontal bending moment (kN m) & -269 & -64 & -46 & 63 \\
\hline Vertical bending moment ( $\mathrm{kN} \mathrm{m}$ ) & -25.196 & -24.913 & -24.284 & -24.830 \\
\hline Vertical displacement (mm) & $-38,35$ & -38.13 & -38.09 & 38.58 \\
\hline Y - Reaction in node 1 (kN) & 41 & 8 & -6 & 8 \\
\hline Y - Reaction in node $2(\mathrm{kN})$ & 41 & -9 & -7 & -8 \\
\hline Z - Reaction in node 1 (kN) & 3.095 & 2.852 & 2.831 & 2.849 \\
\hline Z - Reaction in node 2 (kN) & 3.095 & 2.884 & 2.895 & 2.926 \\
\hline
\end{tabular}

that the maximum values of bending moments are found for the situation where each car gravity centre is in the middle of the span; For the torsion moment, the maximum obtained corresponds to the situation with two cars traveling on the bridge, the gravity centre of the first being at a distance of $31.5 \mathrm{~m}$ from the beginning of the bridge and the later at $9.0 \mathrm{~m}$; For the vertical displacement, the critical situation also occurs with two cars on the bridge, namely when the gravity centre of the first one is at $29.5 \mathrm{~m}$ from the beginning of the bridge and the one of the second at $7.0 \mathrm{~m}$. In the case of the reactions, the maxima happen for two cars on the bridge, one of them being over the supports.

For the illustrative example discussed in this paper, considering the train speed equal to $20 \mathrm{~m} / \mathrm{s}$, it is noted that the number of halfwaves of longitudinal irregularities that produce resonance with the dominant modes of bounce for the wagon or of bending in the vertical plane of the bridge is, respectively, $n=5$ or $n=11.7$. Actually, in the first scenario $(n=5)$, the interaction effort referring to the vertical force presents the same frequency of the vehicle $4^{\text {th }}$ mode; in the second scenario $(n=11.7)$, however, this same effort presents frequency coincident with the first mode of bending in the deck vertical plane. Also for these two scenarios, it is admitted that the presence of irregularities in the rails and in the wheels exists even before the car enters the bridge, thus disregarding the disturbance in the efforts observed at the beginning of the train's dynamic analysis.

The dynamic analyses results, for the two analysed scenarios, were obtained for the same nodes or elements, as performed for quasi-static analysis, and they are presented in Figures 9 and 10. First, analysing the vibration modes found for the bridge and train models, it is worth mentioning that the frequencies of the first five modes of the car $(0.645$ to $1.667 \mathrm{~Hz})$ are much lower than the first vibration mode of the bridge $(3.307 \mathrm{~Hz})$. However, there is proximity between the values obtained for the modes 2 and 3 of the bridge and 6 to 9 of the car, and modes 4 to 6 of the bridge and 10 of the car. Table 3 presents this comparison.

Also with respect to the vibration modes, the scenario with $n=5$ presents a frequency for the vertical interaction force equal to 1.3 $\mathrm{Hz}$, equivalent to the $4^{\text {th }}$ mode of vibration of the car, whereas for the scenario with $n=11.7$, this value corresponds to the first mode of bridge vibration, $(3.3 \mathrm{~Hz})$. This means that although the vehicle and deck modes are far apart and therefore far from a resonance case, the occurrence of this phenomenon due to the proximity of the frequencies of the interaction forces, either with the vehicle, or with the bridge, is possible.

Regarding the force results, Table 4 shows the maximum values obtained in each scenario analysed. For comparison purposes, the results of an analysis performed for the case $n=8.7$ are also presented, in which the frequency of the vertical interaction effort is not close to any mode of vibration, either the bridge or the vehicle.

\section{Conclusions}

The previously expressed expectation that the results obtained for a quasi-static study would be superior to dynamic analyses, for all the efforts considered, is confirmed as presented in Table 4. In addition to the fact that it is a very rigid bridge for the vehicle in question, we must take into account the following aspects that contribute to explain these results: as the span is very small (only $36 \mathrm{~m}$ ), at every moment there will be, during the train passage, in the most unfavourable hypothesis, two vehicles over the bridge (one of them being only partially, because the total length of the wagon is $22.5 \mathrm{~m}$ ); each wagon remains a very small time lapse over the bridge (at a speed of $20 \mathrm{~m} / \mathrm{s}$, only $1.8 \mathrm{~s}$; for higher speeds, time will be inversely proportional to them); the number of wagons in the train being also small (8), the total duration of the dynamic load is also small, giving no opportunity for a more significant growth of the dynamic response, even under a resonant condition with the lower modes of the deck. It is immediate to realize that, in other project situations in which these conditions do not apply, different conclusions can be drawn.

It should also be noted that the dynamic analysis also provided estimation for the maximum vertical acceleration in the middle of the span, reaching a value of $0.57 \mathrm{~ms}^{-2}$ far below the threshold value $5.0 \mathrm{~ms}^{-2}$, often adopted in design criteria for passenger trains, indicating once again that it is a bridge where the vibration response is not critical. Likewise, the maximum dynamic vertical displacement found $(38.58 \mathrm{~mm}$ ) is far below $1 / 600$ of the span of the bridge (60 $\mathrm{mm}$ ), usually taken as the design threshold.

As already noted, for the scenarios where the dominant frequency of one of the interaction forces equals that of a mode of vibration of 
the car or of the bridge, there is an increase in the internal forces with respect to a situation where there is no resonance. This can be observed by comparing the scenarios of $n=5$ or $n=11.7$ with the case of $n=8.7$, where the dominant load frequency does not coincide with that of either the vehicle or the deck in any way. Thus, for railway bridges, a sensible design criterion is to keep a safe distance between the vibration frequencies of the car and those of the deck. It is equally important to keep a safe distance between the dominant frequency of the interaction forces (which depends on the wagon speed and the track imperfections) and those of both the car and the bridge deck this aspect being usually overlooked during the design phase.

Finally, it should be noted that the present case study refers to non-ballast tracks, a contemporary trend especially for high-speed trains. Of course, in the case of ballast tracks, it would be necessary in the finite-element modelling to interpose viscoelastic elements between the node representing the wheel-rail contact and the node representing the bridge deck structure.

\section{References}

[1] ADINA - Automatic Dynamic Incremental Nonlinear Analysis Software: versão 8.9.1. Desenvolvido pela ADINA R\&D, Inc. Massachusetts, 2013. Disponível em: http://www.adina. com. Acesso em 14/03/2016.

[2] AMERICAN RAILWAY ENGINEERING AND MAINTENANCE-OF-WAY ASSOCIATION, AREMA - Manual for Railway Engineering, 2016.

[3] ASSOCIAÇÃO BRASILEIRA DE NORMAS TÉCNICAS, NBR 7187 - Projeto de Pontes de Concreto Armado e de Concreto Protendido - Procedimento - 2003. 13

[4] Clemente, L. G., BORGES L. A. e STUCCHI, F., 1989. Projeto de viaduto unicelular para pista dupla na extensão da linha Norte/Sul do Metrô de São Paulo - Anais do Primeiro Simpósio EPUSP de Estrutura de Concreto.

[5] CHEN, Y. and LI, C. Y., 2000, Dynamic Response of Elevated High-Speed Railway. Journal of Bridge Engineering, Vol. $5, n^{\circ} 2,124-130$.

[6] CORREA, W. L., 2008, Controle das Vibrações Induzidas pela Interação Dinâmica entre Trens-Trilhos-Dormentes-Estrutura de Aço de Pontes Ferroviárias. Tese, COPPE/UFRJ, Rio de Janeiro, RJ, Brasil.

[7] CUNHA, P. G., 2011, Análise Dinâmica de Pontes Ferroviárias: Uma Metodologia Simplificada. Dissertação de Mestrado, Escola Politécnica da Universidade de São Paulo, São Paulo, SP, Brasil.

[8] FRÝBA, L., 1980, Estimation of Fatigue Life of Railway Bridges under Traffic Loads. Journal of Sound and Vibration, 70, 527-541.

[9] LIN, Y. H. and TRETHEWEY, M. W., 1990. Finite Element Analysis of Elastic Beams Subjected to Moving Dynamic Loads. Journal of Sound and Vibration, 136, 323-342.

[10] LIU, K., ROECK, G. and LOMAERT, G., 2009, The Effect of Dynamic Train-Bridge Interaction on the Bridge Response during a Train Passage. Journal of Sound and Vibration, 325, 240-251.

[11] MALKA, M. and HARTNETT, M., 2009. Dynamic Response of Bridges to Moving Trains: A Study on Effects of Random Track Irregularities and Bridge Skewness. Journal Computers \& Structures, 87, 1233-1252.

[12] MOROZ, F. V., 2009, Uma Metodologia para a Análise da Influência no Tráfego de Carros Pesados na Resposta Dinâmica de Pontes Rodoviárias. Dissertação de Mestrado, Escola Politécnica da Universidade de São Paulo, São Paulo, SP, Brasil.

[13] XIA, H., XU, Y. L. and CHAN, T. H. T., 2000, Dynamic Interaction of Long Suspension Bridges with Running Trains. Journal of Sound and Vibration 237, 263-280.

[14] XU, Y. L., XIA, H. and YAN, Q. S., 2003, Dynamic Response of Suspension Bridge to High Wind and Running Train. Journal of Bridge Engineering, Vol. 8, $n^{\circ}$ 1,46-55. 